\title{
PENGARUH DISIPLIN, MOTIVASI KERJA DAN KOMPENSASI TERHADAP KINERJA KARYAWAN YAYASAN PENGEMBANGAN PENDIDIKAN DINAMIKA (YPPD) CIKARANG
}

\subsection{5/akademika.v8i02.323}

\author{
Saga Cindai Alisanda \\ saga.cindai@gmail.com \\ Universitas Mercubuana, Indonesia
}

\author{
Tjiptogoro Dinarjo Soehari \\ tjiptogd@yahoo.com \\ Universitas Mercubuana, Indonesia
}

\begin{abstract}
This study aims to get information about the influence of discipline, work motivation and compensation to employee performance of development Foundation dynamics Cikarang. This study using quantitative approach conducted in five levels of schools; nursery school, elementary school, junior high school, vocational school and college under Development Foundation Dynamics Cikarang. This study conducted by using the method of the survey with analysis lines in the hypothesis testing. In this study sample size of saturated is 101. research focused on three aspects; discipline, motivation and compensation in the Development Foundation Education Dynamics Cikarang. The data collected by the questionnaires and analyzed with analysis path. The results of the analysis concluded that (1) there is a direct influence positive discipline to employee performance Ckarang. (2) there is a direct influence positive motivation to employee performance Cikarang, and (3) there is a direct influence positive compensation to employee performance Cikarang.
\end{abstract}

Keyword: Discipline, Work Motivation, Compensation, Performance

\begin{abstract}
Abstrak: Tujuan dari penelitian ini adalah untuk memperoleh informasi mengenai pengaruh disiplin, motivasi kerja dan kompensasi terhadap kinerja karyawan yayasan pengembangan dinamika (YPPD) cikarang. Penelitian ini menggunakan pendekatan kuantitatif yang dilakukan lima jenjang sekolah TK, SD, SMP, SMK dan perguruan tinggi yang dalam naungan yayasan pengembangan dinamika (YPPD) cikarang. Penelitian ini dilakukan dengan menggunakan metode survei dengan analisis jalur dalam pengujian hipotesis. Dalam penelitian ini jumlah sampel jenuh adalah 101. Penelitian difokuskan pada tiga aspek; disiplin, motivasi kerja dan kompensasi pada yayasan pengembangan pendidikan dinamika (YPPD) cikarang. Data dikumpulkan dengan kuesioner dan dianalisis dengan analisis jalur. Hasil analisis tersebut menyimpulkan bahwa (1) Ada pengaruh langsung positif disiplin terhadap kinerja karyawan (YPPD) cikarang. (2) Ada pengaruh langsung positif motivasi kerja terhadap kinerja karyawan (YPPD) cikarang, dan (3) Ada pengaruh langsung positif kompensasi terhadap kinerja karyawan (YPPD) cikarang.
\end{abstract}

Kata Kunci: Disiplin, Motivasi Kerja, Kompensasi, Kinerja

\section{PENDAHULUAN}


Dalam penelitian ini peneliti mengkelompokan bahwa dalam penguatan kinerja karyawan, peneliti mengambil beberapa variabel seperti disiplin, motivasi kerja dan kompensasi, dimana ketiga variabel ini merupakan suatu permasalahan yang terjadi di Yayasan Pendidikan Pengembangan Dinamika (YPPD) Cikarang. Kinerja Karyawan adalah sebagai hasil kerja yang dicapai oleh individu yang disesuaikan dengan peran atau tugas individu tersebut dalam suatu perusahaan dalam periode tertentu, yang dihubungkan dengan suatu ukuran nilai atau standar tertentu dari perusahaan di mana individu tersebut bekerja. Sebagaimana dijelaskan oleh Mangkunegara (2010:67) yaitu kinerja adalah hasil kerja secara kualitas dan kuantitas yang dicapai seorang karyawan dalam melaksanakan tugas sesuai dengan tanggung jawab yang diberikan kepadanya. Pihak pimpinan atau ketua yayasan menjelaskan bahwa adanya penurunan kinerja karyawan, Kinerja karyawan pada Yayasan Pengembangan Pendidikan Dinamika (YPPD) Cikarang, belum memenuhi standar yang diharapkan. Terdapat beberapa karyawan yang kurang disiplin seperti datang terlambat, masih ada karyawan yang lebih awal keluar kantor untuk istirahat serta terlambat kembali ke mejanya setelah jam istirahat selesai. Dan untuk mengatasi hal-hal tersebut atau pelanggaran tersebut belum ada sanksi tegas, juga tingkat ketidakhadiran yang masih cukup menonjol setiap bulannya. Selanjutnya, peneliti melakukan pencarian dan pengumpulan data sekunder yang di dapatkan dari instansi terkait permasalahan, berdasarkan kenyataan yang telah dijabarkan didapat rekap data kehadiran yang penulis dalam 3 tahun terakhir yakni dari tahun 2015 sampai dengan Desember 2017 untuk kehadiran karyawan minimal 99\%, namun fakta lapangan belum mencapai 99\% karena tertinggi di YPPD cikarang baru mencapai 95\% dan terendah $81 \%$. Adapun Motivasi Kerja adalah pendorong bagi seseorang untuk berperilaku dan bekerja dengan giat dan baik sesuai dengan tugas dan kewajiban yang telah diberikan kepadanya dan merupakan tenaga emosional yang sangat penting untuk sesuatu pekerjaan baru. Untuk mengetahui sejauh mana motivasi kerja memberikan pengaruh terhadap kinerja karyawan, maka peneliti melaksanakan mengelolah data sekunder dan dapat diketahui hanya sebanyak 30 karyawan yang ingin berprestasi dan sisanya 71 karyawan yang tidak ingin berprestasi dari jumlah data sekunder 101 karyawan, Imbalan menjadi alasan utama mengapa kebanyakan orang mencari pekerjaan, dan imbalan juga merupakan motivasi karyawan dalam bekerja. Kemudian peneliti menemukan bahwa intensitas pemberian bonus mengalami penurunan rata-rata 2 tahun terakhir. Bonus yang diberikan YPPD Cikarang dirasa kurang oleh karyawan. Karyawan merasa bonus yang diterima seharusnya bisa lebih besar. Kurangnya kompensasi untuk mengapresiasi karyawan dirasa membuat kinerja karyawan menurun. Karyawan merasa kurang terhadap kompensasi yang diberikan YPPD Cikarang. Pemberian kompensasi berupa bonus atau jabatan tertentu terkadang juga tidak memperhatikan kemampuan kerja karyawannya. Hal ini akan menimbulkan kecemburuan

147|Akademika Jurnal Teknologi Pendidikan Vol.8 No.2 2019 
antar karyawan sehingga mereka merasa ada ketidakadilan dalam pemberian kompensasi. Dengan demikian maka Peneliti melihat suatu kebutuhan yang diperlukan perusahaan dimana tempat saya bekerja (Yayasan Pengembangan Pendidikan Dinamika Cikarang) yaitu adanya penurunan Kinerja Karyawan, yang disebabkan 3 aspek yaitu disiplin, motivasi kerja dan kompensasi, maka peneliti Mengagkat Judul "Pengaruh Disiplin, Motivasi Kerja Dan Kompensasi Terhadap Kinerja Karyawan Yayasan Pengembangan Pendidikan Dinamika (YPPD) Cikarang".

Pengertian Kinerja menurut Miner dalam Sudarmanto (2011:11-12) mengemukakan 4 dimensi yang dijadikan sebagai tolak ukur dalam menilai kinerja, yaitu: a) Kualitas, yaitu: tingkat kesalahan, kerusakan, kecermatan. b) Kuantitas, yaitu jumlah pekerjaan yang dihasilkan. c) Penggunaan waktu dalam bekerja, yaitu tingkat ketidak hadiran karyawan, keterlambatan waktu kerja efektif atau jam kerja hilang. d) Kerjasama dengan orang lain dalam bekerja.

Menurut Malayu Hasibuan (2012:193) berpendapat bahwa: "Kedisiplinan adalah kesadaran dan kesediaan seseorang menaati semua peraturan perusahaan dan norma-norma sosial yang berlaku. Kedisiplinan harus ditegakkan dalam suatu organisasi perusahaan. Tanpa dukungan disiplin karyawan yang baik, sulit bagi perusahaan untuk mewujudkan tujuannya. Jadi, kedisiplinan adalah kunci keberhasilan suatu perusahaan dalam mencapai tujuannya.

Menurut Sihotang (2007: 245-246), motivasi kerja melibatkan dua jenis faktor. Yaitu: 1. Faktor-faktor Individual: a) Kebutuhan-kebutuhan, b) Tujuan-tujuan orang , c) Sikap-sikap, d) Kemampuan-kemampuan orang. 2. Faktor-faktor Organisasi : a) Pembayaran gaji atau upah, b) Keselamatan kesehatan kerja, c) Para mandor (supervisi), d) Para pengawas fungsional.

Menurut Dessler (2005:350) ada 2 (dua) macam bentuk pembayaran kompensasi pegawai yaitu: a) Pembayaran secara langsung (direct financial payment), yaitu: pembayaran dalam bentuk uang yang dilaksanakan secara langsung, sebagai suatu imbalan kepada pegawai yang mencurahkan tenaganya untuk organisasi. Pembayaran secara langsung dapat berupa gaji, komisi, dan bonus. b) Pembayaran tidak langsung (indirect payment), yaitu: suatu pembayaran yang tidak langsung diberikan kepada pegawai yang telah memberikan tenaganya untuk organisasi biasanya berupa tunjangan dan fasilitas.

\section{METODE}

Dalam penelitian ini, penulis menggunakan desain kuantitatif dengan metode explanatory survey. Berdasarkan desain penelitian yang dimaksud, dilakukan analisis uji hipotesis penelitian melalui teknik analisis statistika yang relevan (kuantitatif).Pada penelitian ini penulis menggunakan data primer yang diperoleh dari obsevasi, dan penyebaran kuesioner kepada karyawan Yayasan Pendidikan Pengembangan 
Dinamika (YPPD) Cikarang, Data sekunder diperoleh peneliti dari sumber yang sudah ada yakni berupa dokumen/data karyawan dari HRD. Data penelitian diambil dalam 3 tahun terkahir yaitu tahun 2015 - 2017 di kantor YPPD Cikarang. Dalam penelitian ini, peneliti menggunakan lima skala pengukuran yakni skala Ordinal sebagai skala pengukuran. Adapun populasi dalam penelitian ini adalah karyawan YPPD Cikarang yang berjumlah 101 karyawan. Penentuan jumlah sampel dalam penelitian ini menggunakan metode sampel jenuh, dengan mengambil seluruh karyawan dengan level jabatan yang berjumlah 101 karyawan. Penelitian ini menggunakan analisis regresi linier berganda dengan bantuan software SPSS versi 23 untuk Windows.

\section{HASIL}

Hasil penelitian menujukkan bahwa responden yang menjadi subjek penelitian sebagian besar berusia 31-35 tahun yaitu 33,7\%, namun usia responden dengan jumlah paling sedikit yaitu usia diatas 40 tahun yang hanya $8,9 \%$. Kemudian diperoleh juga bahwa responden pria lebih sedikit dibandingkan dengan responden wanita. Menurut jabatannya penelitian ini hanya mengambik karyawan yang berprofesi sebagai staff. Kemudian menurut tingkat penerimaan gaji, 33,7\% menerima gaji antara 2-3 juta, ada $27,7 \%$ responden menerima gaji antara $1-2$ juta, selanjutnya $21,8 \%$ responden menerima gaji kurang dari 1 juta dan $11,9 \%$ menerima gaji antara 3-4 juta, sedangkan hanya ada 5\% responden yang menerima gaji diatas 4 juta.

Uji Validitas dan Reliabilitas menggunakan Alpha Cronbach's, dimana menggunakan sampel sebanyak 30 orang, dimana dalam penelitian ini setiap instrument pernyataan sebanyak 15 butir, baik variabel bebas dan terikat, dimana dari 60 pernyataan semuanya valid karena $r$ hitung $>0,3$ dan terkait reliabilitas setiap variabel yaitu Disiplin (X1) sebesar 0,962, Motivasi Kerja (X2) sebesar 0,972, Kompensasi (X3) sebesar 0,953, dan Kinerja Karyawan (Y) sebesar 0,951 artian semuanya dinyatakan reliabel karna $r$ hitung $>0,60$.

Uji Normalitas dengan menggunakan histogram menunjukan bahwa kurvanya normal dikarenakan kurva yang berbentuk/ menyerupai lonceng, sedangkan menggunakan uji Normal P-Plot menunjukan bahwa data-data yang digunakan berada di sekitar garis normal (diagonal) tersebut dan terakhir peneliti melakukan uji normalitas dengan menggunakan Statistic non-parametric Kolmogorov-Smirnov, Hasil uji normalitas dengan onesample Kolmogorov-Smirnov test dari masing-masing variabel, yang mana menghasilkan nilai Asymp. Sig. (2-tailed) yaitu < 0,05 pada variabel Kinerja dan Kompensasi. Artinya variabel kinerja dan variabel kompensasi tidak berdistribusi normal. Maka dilakukan z score dari uji z score dan diperoleh bahwa data seluruh nilai $z$ score berada diatas nilai $-2,5$ dan di bawah nilai 2,5 sehingga data dapat dianalisis lebih lanjut. Maka dilakukan

149|Akademika Jurnal Teknologi Pendidikan Vol.8 No.2 2019 
z score dari uji z score dan diperoleh bahwa data seluruh nilai z score berada diatas nilai $-2,5$ dan di bawah nilai 2,5 sehingga data dapat dianalisis lebih lanjut.

Uji lineritas ini dilakukan satu persatu antara $\mathrm{X} 1$ dengan $\mathrm{Y}, \mathrm{X} 2$ dengan $Y$ dan $X 3$ dengan $Y$, dimana nilai $P$ dilihat dari nilai sig deviation from linearity. Berikut masing-masing nilai $P$; untuk $X 1$ terhadap $Y$ yaitu 0.000 , sedangkan untuk nilai $P$; $X 2$ terhadap $Y$ yaitu 0.000 (X2), dan untuk nilai $P$ : X3 terhadap $Y$ yaitu 0,000 (X3) sehingga di artikan bahwa masingmasing nilai $p>0,05$ hal ini dapat disimpulkan bahwa terdapat hubungan linear yang signifikan antara variabel bebas dan variabel terikat.

Uji Multikolinearitas dilakukan dari data Collinearity Statistics, yang mana menunjukkan bahwa nilai Tolerance X1 sebesar 0.369, X2 Sebesar 0.166 , dan X3 sebesar 0,164 dimana tidak ada yang lebih kecil dari 0,10 dan nilai VIF pada X1 sebesar 2,711, X2 Sebesar 6,023, X3 Sebesar 6,081 dimana masing-masing variabel jauh lebih kecil dari 10, berarti dapat disimpulkan bahwa tidak terjadi multikolinearitas antar variabel independen dalam model regresi.

Pada Uji Heterokedastisitas dimana hasil dari scatterplot dapat dilihat bahwa data tidak membentuk suatu pola tertentu dan titik-titik data tidak hanya mengumpul di atas atau di bawah angka 0 saja melainkan menyebar di atas dan di bawah. Jadi, dapat disimpulkan bahwa tidak ada problem heterokedastisitas pada data residual.

Uji Regresi Linier Berganda

Tabel 1.

Hasil Regresi Hasil Uji Regresi Linier Berganda Coefficientsa Regresi Berganda

\begin{tabular}{lllllc}
\hline \multirow{2}{*}{ Model } & \multicolumn{4}{l}{$\begin{array}{l}\text { Unstandardized } \\
\text { Coefficients }\end{array}$} & $\begin{array}{l}\text { Standardized } \\
\text { Coefficients }\end{array}$ \\
\cline { 2 - 6 } & $\mathbf{B}$ & Std. Error & Beta & T & Sig \\
\hline (Constant) & $-0,070$ & 0,110 & & $-0,635$ & 0,527 \\
\hline Disiplin & 0,409 & 0,045 & 0,416 & 9,042 & 0,000 \\
\hline Motivasi Kerja & 0,178 & 0,072 & 0,171 & 2,494 & 0.014 \\
\hline Kompensasi & 0,456 & 0,072 & 0,438 & 6.352 & 0,000 \\
\hline
\end{tabular}

Berikut Penjelasan persamaan regresi yang diperoleh dari table diatas sebagai berikut :

1. $Y=-0,070+0,409 \times 1+0,178 \times 2+0,456 \times 3+e$.

2. Angka koefisien regresi untuk variabel Disiplin (X1) sebesar 0,409 . Menyatakan bahwa apabila Variabel X2 dan X3 diangap nol (tidak dijalankan), maka variabel Disiplin (X1) akan mempengaruhi kinerja karyawan $(Y)$ sebesar 0,409.

3. Angka koefisien regresi untuk variabel Motivasi Kerja (X2) sebesar 0,178 . Menyatakan bahwa apabila Variabel X1 dan X3 diangap nol (tidak dijalankan), maka variabel Motivasi (X2) akan mempengaruhi kinerja karyawan (Y) sebesar 0,178.

4. Angka koefisien regresi untuk variabel Kompensasi (X3) sebesar 0,456. Menyatakan bahwa apabila Variabel X1 dan X2 diangap nol (tidak 
dijalankan), maka variabel Kompensasi (X1) akan mempengaruhi kinerja karyawan $(Y)$ sebesar 0,456.

Pada Uji $T$ secara parsial Disiplin memiliki hubungan positif dan signifikan terhadap Kinerja Karyawan YPPD Cikarang dengan hasil uji $\mathrm{t}=$ $9,042>$ dari nilai tabel t yaitu $=1,98472$ dan tingkat signifikansi $0,000<$ dari 0,05 dan nilai b1 $=0,409>0$, berikutnya Variabel Motivasi kerja memiliki hubungan positif dan signifikan terhadap Kinerja Karyawan YPPD Cikarang dengan hasil uji $t=2,494>$ dari nilai tabel $t$ yaitu $=1,98472$ dan tingkat signifikansi $0,014<$ dari 0,05 dan nilai b2 $=0,178>0$, Selanjutnya Variabel Kompensasi memiliki hubungan positif dan signifikan terhadap Kinerja Karyawan YPPD Cikarang dengan hasil uji $t=6,352>$ dari nilai tabel t yaitu $=1,98472$ dan tingkat signifikansi $0,000<$ dari 0,05 dan nilai b3 $=0,456>0$.

Pengujian uji $\mathrm{F}$ terlihat dari hasil Uji Anova nilai $\mathrm{F}$ terlihat bahwa $\mathrm{F}$ hitung $>\mathrm{F}$ tabel $(393,902>2,70)$. Keputusan yang diambil berdasarkan hal tersebut adalah Ho ditolak, Ha diterima, sehingga dapat disimpulan bahwa Disiplin (X1), Motivasi Kerja (X2) dan Kompensasi (X3) berpengaruh secara signifikan terhadap Kinerja Karyawan (Y) secara bersama-sama (simultan).

Uji Rsquare dengan melakukan pengujian koefisien determinasi terlihat bahwa nilai $r$ square adalah sebesar 0,924, yang artinya bahwa variabel Motivasi (X1), Disiplin Kerja (X2) dan Kompensasi (X3) memiliki pengaruhi terhadap variabel Kinerja karyawan $(Y)$ sebesar 92,4\%, sedangkan sisanya sebesar $7,6 \%$ dipengaruhi oleh variabel lainnya yang tidak diteliti dalam pelitian ini.

\section{PEMBAHASAN}

1) Terdapat pengaruh yang positif dan signifikan antara variabel Kinerja Kerja (X1) terhadap variabel Kinerja Karyawan (Y) YPPD. Berdasarkan hasil akumulasi dari angket jawaban yang telah dikumpulkan dari responden, kemudian dianalisa statistik menggunakan program statistik SPSS ver. 24 terbukti bahwa terdapat pengaruh antara variabel Motivasi (X1) terhadap variabel Kinerja Karyawan (Y). Disiplin berpengaruh signifikan terhadap kinerja karyawan YPPD CikarangHasil analisis dengan uji t menghasilkan nilai $\mathrm{t}$ hitung $=$ 9,042 dengan probabilitas signifikansi yaitu 0,000 .

2) Terdapat pengaruh yang positif dan signifikan antara variabel Motivasi Kerja (X2) terhadap variabel Kinerja Karyawan (Y) YPPD. Seperti halnya uji hipotesis sebelumnya telah terbukti bahwa terdapat pengaruh yang positif dari variabel Motivasi Kerja (X2) terhadap variabel Kinerja Karyawan (Y). Motivasi berpengaruh signifikan terhadap kinerja karyawan YPPD Cikarang. Hasil analisis dengan uji t menghasilkan nilai t hitung = 2,494 dengan probabilitas signifikansi yaitu 0,014. 
3) Terdapat pengaruh yang positif dan signifikan antara variabel Kompensasi (X3) terhadap variabel Kinerja Karyawan (Y) YPPD. Kompensasi berpengaruh signifikan terhadap kinerja karyawan YPPD Cikarang. Hasil analisis dengan uji t menghasilkan nilai t hitung $=6,352$ dengan probabilitas signifikansi yaitu 0,000 . Dengan melihat tabel t pada taraf signifikansi $0,05(5 \%)$ untuk uji dua arah dan degree of freedom (df) $=$ jumlah sampel - jumlah variabel $=101-4=97$ diperoleh nilai t tabel $=$ 1,98472. Kompensasi (X3) mempunyai pengaruh terhadap variabel Kinerja Karyawan (Y) sebesar $70 \%$ (tabel 19). Sedangkan persamaan regresi kedua variabel (tabel 27 ) adalah $Y=8,785+1,428 X 3$. Persamaan ini mengindikasikan bahwa setiap kenaikan satu poin dari variabel $Y$ akan meningkatkan variabel X2 sebesar 1,428 pada konstanta 8,785.

4) Terdapat pengaruh yang positif dan signifikan antara variabel Disiplin (X1), Motivasi Kerja (X2) dan Kompensasi (X3) terhadap variabel Kinerja Karyawan (Y) YPPD. Hasil analisis dengan uji $F$ menghasilkan nilai $t$ hitung $=393,902$ dengan probabilitas signifikansi yaitu 0,000.

\section{KESIMPULAN}

Berdasarkan hasil pengujian hipotesis tentang pengaruh disiplin, motivasi kerja dan kompensasi terhadap kinerja karyawan yayasan pengembangan pendidikan dinamika (YPPD) cikarang dapat disimpulkan sebagai berikut:

1) Disiplin secara parsial berpengaruh positif dan signifikan terhadap kinerja karyawan YPPD Cikarang dengan koefisien (b1) =0,416 dan dan $\mathrm{t}$ hitung $=9,042$ serta sig $<0,05$.

2) Motivasi kerja secara parsial berpengaruh positif dan signifikan terhadap kinerja karyawan YPPD Cikarang dengan koefisien (b2) $=0,171$ dan dan thitung $=2,494$ serta sig $<0,05$.

3) Kompensasi secara parsial berpengaruh positif dan signifikan terhadap kinerja karyawan YPPD Cikarang dengan koefisien (b3) $=0,438$ dan $t$ hitung $=6,352$ serta sig $<0,05$. Disiplin, motivasi kerja dan kompensasi secara simultan signifikan terhadap kinerja karyawan YPPD Cikarang dengan Fhitung $=393,902$ dan sig $<0,05$.

\section{SARAN}

Berdasarkan hasil penelitian ini peneliti memberikan saran untuk manajemen YPPD Cikarang sebagai berikut :1) dalam meningkatkan aspek kualitas kerja, manajemen YPPD Cikarang dapat memprioritaskan pada faktor tujuan dan dan kemampuan karyawan, motivasi kerja dari faktor organisasi seperti pembayaran gaji, keselamatan kerja maupun faktor pengawasan, serta kompensasi tidak langsung yang mencangkup tungjangan dan fasilitas, 2) dalam meningkatkan aspek kuantitas, penggunaan waktu dalam bekerja dan kerjasama dengan orang lain dalam bekerja, manajemen YPPD Cikarang dapat memprioritaskan pada berbagai faktor utama seperti balas jasa, sanksi, ketegasan, hubungan 
manusia, faktor-faktor motivasi individu (kebutuhan-kebutuhan, tujuan individu, sikap dan kemampuan individu), serta pemberian kompensasi langsung yang mencangkup gaji, komisi dan bonus. Berdasarkan penjabaran hasil penelitian di atas, maka peneliti memberikan saran kepada peneliti selanjutnya, untuk dapat meneliti hal-hal lain yang bersifat konstruktif diluar penelitian ini seperti : Kompetensi, Pelatihan, Perkembangan Karir, Lingkungan kerja dan Kepuasan kerja, terhadap kinerja karyawan YPPD Cikarang, dengan harapan hasil penelitian dari peneliti selanjutnya dapat melengkapi dan memberikan input yang berguna bagi pihak manajemen untuk meningkatkan kinerja karyawan secara optimal dan objektif.

\section{DAFTAR PUSTAKA}

A.A Anwar Prabu Mangkunegara. (2013). Manajemen Sumber Daya Manusia. Bandung: Perusahaan, Remaja Rosdakarya.

Abdurahman Fathoni. (2012). Metodologi Penelitian dan Teknik Penyusunan. Jakarta: PT Rineka Cipta.

Agung Setiawan. (2013). Pengaruh Disiplin Kerja Dan Motivasi Terhadap Kinerja Karyawan Pada Rumah Sakit Umum Daerah Kanjuruan Malang.

Agus Supriyono. (2009). Cooperative Learning. Yogyakarta: Pustaka Pelajar.

Ahmed, Ashfaq, dan Muhammad Ramzan. (2013). Effects of Job Stress on Employess Job Performance A Study on Banking Sector of Pakistan.

Akbar \& Usman. (2013). Metode Penelitian Sosial. Jakarta: Bumi Aksara.

Ambarita Biner, Paningkat Siburian, Benyamin Situmorang dan Sukarman Purba. (2014). Perilaku Organisasi. Bandung: Alfabeta.

Ardana, I Komang dkk. (2012). Manajemen Sumber Daya Manusia. Yogyakarta: Graha ilmu.

Arifin, \& Barnawi. (2012). Etika dan Profesi Kependidikan. Jogjakarta: Arruzz Media.

Arikunto. (2013). Prosedur Penelitian: Suatu Pendekatan Praktek. Jakarta: Rineka Cipta. 
Azwar, Saifuddin. (2012). Metode Penelitian. Yogyakarta: Pustaka Pelajar.

Bangun, Wilson. (2012). Manajemen Sumber Daya Manusia. Jakarta: Erlangga.

Bonusia. (2013). Hubungan Antara Disiplin Kerja Dengan Kualitas Pelayanan Concierge Pada Hotel Sahid Jaya Solo.

Cushway, Barry. (2012). Human Resource Management. Jakarta: PT. Gramedia.

Dwipayana, Ari. (2014). Membangun Good Governance di Desa. Yogyakarta: IRE Press.

Dinarjo Soehari Tjiptogoro.(2017). Performance Improvement Through Human Capital Strategic For Civil Servant. International Journal Of Applied Business amd Economic Research. Vol.15 No. Serial Publications Pvt. Ltd.

Fahmi, Irham. (2013). Perilaku Organisasi. Teori, Aplikasi Dan Kasus. Bandung: Alfabeta.

Garry Dessler, (2015). Human Resource Management. Edisi Sebelas, New Jersey : Pearson Education, Inc.

Ghozali, Imam. (2015). Analisis Multivariate Dengan Program SPSS. Cetakan Empat. Badan Penerbit Universitas diponegoro. Semarang

Gujarati, Damodar N. (2012). Ekonometrika Dasar. Jakarta: Penerbit Erlangga.

Hasibuan, Malayu S.P. (2014). Manajemen Sumber Daya Manusia. Jakarta: PT Bumi Aksara.

Hughes, dkk. (2012). Leadership: Memperkaya Pelajaran dari Pengalaman, edisi 7. Jakarta: Salemba Humanika.

Kadarisman, M. (2012). Manajemen Pengembangan Sumber Daya Manusia, Edisi Pertama, Cetakan pertama, Rajawali Press, Jakarta.

Laksmi Riani. (2013). Asri Manajemen SDM Masa Kini, Yogyakarta: Graha IImu.

Muchdarsyah Sinungan. (2012). Produktivitas Apa dan Bagaimana. Jakarta: Bumi Aksara. 
Mudrajad Kuncoro. (2013). Metode Kuantitatif Teori dan Aplikasi Untuk Bisnis dan Ekonomi, Edisi Pertama. Yogyakarta: Penerbit UPP AMP YPKN.

Munandar, A. S. (2014). Psikologi industri dan organisasi. Tangerang: UIPress.

Murty, Hudiwinarsih. (2012). Pengaruh Kompensasi, Motivasi, dan Komitmen Organisasional Terhadap Kinerja Karyawan Bagian Akuntansi (Studi Kasus pada Perusahaan Manufaktur Di Surabaya). Jurnal The Indonesian Accounting Review Vol. 2. STIE Perbanas. Surabaya.

Nawawi, Hadari. (2013). Manajemen Sumber Daya Manusia Untuk Bisnis yang Kompetitif. Yogyakarta: Gajah Mada University Press.

Notoatmodjo S. (2012). Promosi Kesehatan dan Perilaku Kesehatan. Jakarta: PT Rineka Cipta.

Nurjaman, Kadar. (2014). Manajemen Personalia. Bandung : CV Pustaka Setia.

Panggabean, Mutiara Sibarani. (2014). Manajemen Sumber Daya Manusia. Jakarta: Ghalia Indonesia.

Purwanto, Ngalim.(2013). Psikologi Pendidikan. Bandung: Rosdakarya.

Rivai, Veithzal dan Ella Djauhari Sagala, (2013), Manajemen Sumber Daya Manusia Untuk Perusahaan. Jakarta: Rajawali Pers.

Riyadi, Muclisin. (2012). Pengertian, Indikator dan Faktor yang Mempengaruhi Kinerja.

Safwan., Nadirsyah., dan Abdullah. (2014). Pengaruh Kompetensi dan Motivasi terhadap Kinerja Pengelolaan Keuangan Daerah Pada Pemerintah Kabupaten Pidie Jaya. Jurnal Akuntansi Volume 3, No. 1, Februari 2014 pp. 133- 139.

Sastrohadiwiryo, Siswanto, B. (2015). Manajemen Tenaga Kerja Indonesia Pendekatan Administratif dan Operasional. Jakarta: bumi Aksara.

Saydam, Gouzali, (2012), Manajemen Sumber Daya Manusia, Cetakan Kedua, Jakarta.

Septawan dkk. (2014). Manajemen Personalia Dan Sumber Daya Manusia Yogyakarta BPFE, Pers. 
Sinambela, Lijan. (2012). Kinerja Pegawai: Teori, Pengukuran dan Implikasi. Yogyakarta: Graha IImu.

Sudarmanto, (2015). Metode Penelitian Kuantitatif, Kualitatif dan $R$ \& $D$. Bandung: Alfabeta.

Sunyoto, Danang. (2013). Teori, Kuesioner, dan Analisis Data Sumber Daya Manusia dalam Organisasi Sekolah. Yogyakarta: Multi Presindo.

Sutrisno, Edi. (2014). Manajemen Sumber Daya Manusia Edisi Cetakan ke-11. Jakarta: Kencana Pranadamedia Group.

Tjiptogoro, Djumarno. (2018), The Strategic Role of Management of Human Resources to Prevent Corruption. Vol 3, Number 3, 2018. Journal of Business and Economics Review. Global Academy of Training \& Research (GATR) Enterprice.

Tjiptogoro, Iffah. (2017), Analysis of Strategic Factors of Human Resources Management for Corruption Prevention. Volume 15, Number 6, 2017. International Journal of Applied Business and Economic Research. Serial Publications Pvt. Ltd.

Tjiptogoro, Iffah. (2017), Performance Improvement Through Human Capital Stategic For Civil Sevant. Volume 24, Number 6, 2017. International Journal of Applied Business and Economic Research. Serial Publications Pvt. Ltd.

Veithzal Rivai, Dkk. (2014). Manajemen Sumber Daya Manusia Untuk Perusahaan Dari Teori Ke Praktik. Depok. PT Rajagrafindo Persada.

Wibowo, (2014). Manajemen Kinerja, Edisi ke-empat, Rajawali Pers, Jakarta.

Wiratama Jaka Nyoman I, Sintaasih Ketut Desak, (2013). Pengaruh Kepemimpinan, Diklat, dan Disiplin Kerja Terhadap Kinerja Karyawan PDAM Tirta Mangutama Kabupaten Badung. Fakultas Ekonomi Universitas Udayana, Bali - Indonesia

Wursanto. (2011). Dasar-Dasar Manajemen Personalia. Jakarta: Dian Pustaka. 